\title{
ANALISIS COST OF FUND UNTUK MENENTUKAN BASE LENDING RATE SELAMA COVID-19 DI PT. BPR TRIDARMA PUTRI KLUNGKUNG
}

\author{
al Wayan Sunia, bNi Putu Linda Kusumawati, bl Made Suidarma \\ ${ }^{a b c}$ Universitas Pendidikan Nasional \\ wayansunia@undiknas.ac.id
}

\begin{abstract}
ABSTRAK
Bank BPR adalah salah satu lembaga keuangan yang dimana kegiatan sehari harinya memberikan kredit kepada masyarakat dan menghimpun dana dari masyarakat dalam bentuk deposito berjangka, dan tabungan. Dalam hal penerimaan dana masyarakat PT. BPR. Tridarma Putri Klungkung memberikan jasa bunga. Selanjutnya jasa bunga yang dikeluarkan oleh bank adalah biaya Dana simpanan untuk deposito berjangka dan tabungan yang disebut Cost Of Fund..Berdasarkan uraian tersebut peneliti tertarik untuk mengalisis Cost Of Fund Untuk Menentukan Base Lending Rate Selama Covid-19 Di PT. BPR Tridarma Putri Klungkung. Penelitian ini dilakukan di Kabupaten klungkung menggunakan jenis data kuantitatif dan kualitatif yang bersumber data kuantitatif yang dikumpulkan dengan teknik dokumentasi, observasi, wawancara dan internet yang dianalisis secara analisis kuantitatif dan kualitatif. Adapun hasilnya bahwa Cost of fund (biaya dana ) tabungan seharusnya sebesar 3,86\%, Sedangkan senyatanya Cost of fund (biaya dana) tabungan yang diberikan/berlaku sekarang adalah sebesa $4 \%$. berarti masih ada selisih sebesar 0,14\%. hasil perhitungan Cost of fund (biaya dana) deposito seharusnya sebesar 6,75 \%, Sedangkan senyatanya Cost of fund (biaya dana) deposito yang diberikan/berlaku sekarang adalah sebesar 8,00\%. berarti masih ada selisih sebesar 1,25\%. Sedangkan hasil perhitungan Base Lending Rate (Suku Bunga Dasar Pinjaman) seharusnya sebesar 21,65\%, Sedangkan kenyatanya Cost of fund (Suku Bunga Dasar Pinjaman) yang diberikan/berlaku sekarang adalah sebesar 22,80\%. berarti masih ada selisih sebesar 1,15\% Di PT. BPR Tridarma Putri Klungkung.
\end{abstract}

Kata Kunci : Cost of fund dan Base Lending Rate

\begin{abstract}
Bank BPR is one of the financial institutions where daily activities provide credit to the public and collect funds from the public in the form of time deposits and savings. In terms of receiving public funds, PT. BPR. Tridarma Putri Klungkung provides flower services. Furthermore, the interest service issued by the bank is the cost of savings funds for time deposits and savings called Cost Of Fund. Based on this description, the researcher is interested in analyzing the Cost of Fund to Determine the PostCovid-19 Base Lending Rate at PT. BPR Tridarma Putri Klungkung. This research was conducted in Klungkung Regency using quantitative and qualitative data types which are sourced quantitative data collected by documentation, observation, interview and internet techniques which are analyzed by quantitative and qualitative analysis. The result shows that the cost of funds for savings should be $3.86 \%$, while in fact the cost of funds for savings that is currently given is $4 \%$. means that there is still a difference of $0.14 \%$. the calculation result of the Cost of fund (cost of funds) for deposits should be $6.75 \%$, while in fact the cost of funds (cost of funds) deposits given / in effect now is $8.00 \%$. means that there is still a difference of $1.25 \%$. Meanwhile, the calculation result of the Base Lending Rate should be $21.65 \%$. In fact, the cost of funds currently given / applicable is $22.80 \%$. means that there is still a difference of $1.15 \%$ at PT. BPR Tridarma Putri Klungkung.
\end{abstract}


Keywords: Cost of funds and Base Lending Rate

\section{PENDAHULUAN}

Bank Perkreditan Rakyat (BPR) merupakan salah satu lembaga keuangan yang mempunyai peran paling penting dalam terlaksananya pemerataan ekonomi bagi masyarakat Indonesia. Hal tersebut disebabkan karena BPR adalah salah satu lembaga keuangan yang mempunyai fungsi untuk menyalurkan dana kepada masyarakat kecil yang membutuhkan yang tidak dapat dijangkau oleh bank umum lainnya, Sehingga pada tahun 2017 dan tahun 2018 terjadi peningkatan pencapaian produk tabungan dan kredit sedangkan di produk deposito mengalami penurunan. Begitu juga ditahun 2018 ke tahun 2019 semua produk mengalami peningkatan, artinya hal tersebut mencerminkan bahwa PT. BPR Tridarma Putri Klungkung masih dipercaya oleh masyarakat. Namun kenyataan bank dalam menentukan tingkat suku bunga kredit masih mempergunakan rata-rata harga pasar dengan membandingkan beberapa Bank Perkreditan Rakyat (BPR) yang ada di Kabupaten Klungkung. Sedangkan PT. BPR Tridarma Putri Klungkung masih memberikan tingkat suku bunga kredit di atas rata-rata suku bunga pasar sehingga dengan demikian PT. BPR Tridarma Putri harus menurunkan tingkat suku bunga kreditnya supaya mampu bersaing dengan BPR yang ada di Kabupaten Klungkung. Berdasarkan uraian diatas peneliti tertarik untuk meneliti tentang Analisis Cost Of Fund Untuk Menentukan Base Lending Rate Pasca Covid-19 Di PT. BPR Tridarma Putri Klungkung.

\section{LANDASAN TEORI}

Berdasarkan Undang-Undang No. 7 Tahun 1992, Bank Perkreditan Rakyat (BPR) adalah bank melaksanakan kegiatan usaha secara konvensional atau berdasarkan prinsip syariah yang dalam kegiatannya tidak memberikan jasa dalam lalu lintas pembayaran. Bank Perkreditan Rakyat (BPR) didefinisikan oleh Undang-Undang Nomor 10 Tahun 1998 sebagai bank yang melaksanakan kegiatan usaha secara konvensional dan/atau berdasarkan prinsip syariah yang dalam kegiatannya tidak memberikan jasa dalam lalu-lintas pembayaran.

Menurut Dahlan Siamat dalam bukunya yang berjudul Manajemen Lembaga Keuangan Edisi Kelima Kegiatan-kegiatan usaha yang diperkenalkan bagi BPR secara umum adalah :

1. Menghimpun dana dari masyarakat dana dalam bentuk simpanan berupa deposit berjangka, tabungan, dan/atau bentuk lainnya yang dipersamakan dengan itu.

2. Memeberikan kredit.

3. Menyediakan pembiayaan dan penetapan dana berdasarkan prinsip syariah.

4. Menempatkan dananya dalam bentuk Sertifikat Bank Indonesia (SBI), deposito berjangka, dan/atau tabungan dapa bank lain.

Dalam hal ini kegiatan penghimpunan dana dibagi kedalam 3 jenis yaitu :

a. Simpanan Giro (Demand Deposit)

Giro adalah simpanan dana pihak ketiga pada bank yang penarikannya dapat dilakukan setiap saat dengan menggunakan cek, bilyet giro dan surat kuasa pembayaran lainnya atau dengan pemindahbukuan dalam artian bahwa tidak dapat ditarik secara tunai.

b. Simpanan Tabugan (Saving Deposito)

Tabungan adalah simpanan pihak ketiga pada bank yang penarikannya hanya dapat dilakukan menurut syarat-syarat tertentu yang telah disepakati seperti slip penarikan, buku tabungan, kartu ATM, atau sarana lainnya tetapi tidak dapat ditarik dengan cek, bilyet giro, atau alat lainnya yang dapat dipersamakan dengan itu.

c. Simpanan Deposito (Time Deposit)

Deposito atau simpanan berjangka adalah simpanan dana pihak ketiga pada bank yang penarikannya hanya dapat dilakukan dalam jangka waktu tertentu berdasarkan perjanjian antara pihak bank dengan nasabah yang bersangkutan penarikannya dapat menggunakan bilyet giro atau sertifikat deposito. 
Selanjutnya Menurut Ismail (2010), biaya dana merupakan biaya yang dikeluarkan oleh bank dalam rangka menghimpun dana pihak ketiga. Artinya, bank akan menghitung biaya yang dikeluarkan atas setiap dana yang berhasil dihimpunnnya dari berbagai sumber dana setelah diperhitunghkan adanya cadangan dana yang wajib dipelihara oleh setiap bank. Setiap jenis sumber dana memiliki suku bunga yang berbeda-beda. Oleh karena itu, tinggi rendahnya biaya dana rata-rata tergantung pada komposisi sumber dana yang berhasil dihimpun.

Menurut Kasmir (2007), biaya dana atau cost of fund adalah total biaya bunga yang dikeluarkan oleh bank untuk memperoleh dana simpanan baik dalam bentuk simpanan giro, tabungan maupun deposito. Total biaya dana ini harus dikurangi dengan cadangan wajib atau Reserve Requirement (RR) yang telah ditetapkan oleh pemerintah.

Menurut Kasmir, (2002: 121) suku bunga bank dapat diartikan sebagai balas jasa yang diberikan oleh bnak yang berdasarkan prinsip konvensional kepada nasabah yang membeli atau menjual produknya. Sadomo Sukimo (2006:375) menyatakan suku bunga adalah bunga yang dinyatakan sebagai persentasi dari modal. Dalam kegiatan perbankan sehari-hari ada 2 macam bunga yang diberikan kepada nasabahnya, yaitu :

1. Bunga Simpanan

Bunga yang diberikan sebagai rangsangan atau balas jasa bagi nasabah yang menyimpan uangnya di bank. Bunga simpanan merupakan harga yang harus dibayar kepada nasabahnya. Sebagai contoh : jasa giro, bunga tabungan, bunga deposito.

2. Bunga pinjaman

Bunga yang diberikan kepada para peminjam atau harga yang harus dibayar oleh nasabah peminjam kepada bank. Sebagai contoh bunga kredit.

Sedangkan penentuan tingkat suku bunga kredit akan dipengaruhi oleh beberapa faktor yaitu sebagai berikut :

a. Cost of Loanable Funds (COLF)

Tingkat Cost of Loanable Funds dipengaruhi oleh struktur dana, komposisi dana, tingkat bunga dana (borrowing rate) dan reserve requirement. Semakin tinggi tingkat bunga dan reserve requirement, maka semakin tinggi Cost of Loanable Funds dan akan terjadi sebaliknya, apabila borrowing rate dan reserve requirement turun. Cost of Loanable Funds yaitu ditempatkan yang dioperasionalkan (ditempatkan) untuk memperoleh pendapatan. Dana operasional adalah total dana yang dihimpun dikurangi dengan unloanable funds (dana yang tidak ditempatkan pada aktiva produktif untuk tujuan berjagajaga/cadangan).

b. Overhead Cost (OHC)

Biaya ini merupakan biaya selain bunga yang dikeluarkan dalam proses penghimpunan dana, misalnya : biaya tenaga kerja, biaya sewa kantor, biaya penyusutan, biaya transport, biaya promosi, dan biaya lainnya.

c. Risk Cost (Bad Debt)

Biaya ini ditentukan dari besarnya cadangan penghapusan kredit, setelah cadangan penghapusan kredit dihitung berdasarkan data historis.

d. Spread

Spread merupakan margin yang diproyeksikan. Dalam perencanaan bunga kredit, spread merupakan perbandingan proyeksi spread terhadap baki debet atau loanable funds. Besarnya spread pada tingkat operasional sering dipengaruhi oleh kualitas jaminan kredit, jangka waktu kredit, dan reputasi debitur.

e. Tingkat Pajak (Tax Rate)

Suku bunga kredit dapat ditetapkan tegantung dari besarnya pajak yang ditanggung atas penempatan dana pada kredit. Tax rate diperhitungkan dalam base lending rate yang besarnya tergantung dari proyeksi spread yang ditentukan.

\section{METODE PENELITIAN}

Penelitian ini adalah PT. BPR Tridarma Putri yang beralamat di Jl. Diponegoro, No. 25 Semarapura Kelod Kangin, Klungkung, Bali 80761. Pertimbangan penulis memilih PT. BPR Tridarma Putri sebagai objek penelitian karena PT. BPR Tridarma Putri Klungkung masih 
memberikan tingkat suku bunga kredit di atas rata-rata suku bunga pasar sehingga dengan demikian PT. BPR Tridarma Putri harus menurunkan tingkat suku bunga kreditnya supaya mampu bersaing dengan BPR yang ada di Kabupaten Klungkung, penelitian ini menggunakan jenis data kuantitatif dan kualitatif yang bersumber data kuantitatif yang dikumpulkan dengan teknik dokumentasi, wawancara dan internet yang dianalisis secara analisis kuantitatif dan kualitatif.

\section{HASIL PENELITIAN}

\section{Perhitungan Biya Dana ( Cost of Fund)}

Dalam menghitung biaya dana (Cost of Fund) yang bersumber dari tabungan dan deposito terlebih dahulu harus mencari biaya dana rata-rata tertimbang dari masingmasing tersebut, karena sumber-sumber dana ini memiliki tingkat bunga yang ditentukan berdasarkan jumlah saldo dan jangka waktu. Bank memberikan jasa deposito berjangka berdasarkan tingkat bunga yang dipengaruhi oleh jangka waktu jatuh temponya, demikian juga sumber dana dari tabungan, dimana tingkat bunganya di hitung dari jumlah saldo tabungan dan lamanya mengendap di bank.

Dengan adanya karakteristik tersebut, maka untuk mengetahui biaya dana bank harus dihitung berdasarkan rata-rata tertimbang dilihat pada tabel berikut ini :

\begin{tabular}{|c|c|c|c|}
\hline Tahun & $\begin{array}{c}\text { Jumlah } \\
\text { Tabungan } \\
(\mathrm{Rp})\end{array}$ & $\begin{array}{c}\text { Biaya Dana } \\
\text { Tabungan } \\
(\%)\end{array}$ & $\begin{array}{c}\text { Tingkat } \\
\text { Bunga } \\
(\%)\end{array}$ \\
\hline 2019 & 44.002 .744 .792 & 1.698 .636 .036 & 3,86 \\
\hline
\end{tabular}

Sumber : PT. BPR Tridarma Putri Klungkung

Dari tabel di atas dapat dicari biaya dana (Cost of Fund) rata-rata tertimbang untuk tabungan sebagai berikut : Cost of Fund tabungan $=1.698 .636 .036 / 44.002 .744 .792 \mathrm{x}$ $100 \%=3,86 \%$.

Sedangkan untuk biaya dana (Cost of Fund) rata-rata tertimbang Deposito di PT. BPR Tridarma Putri Klungkung Tahun 2019 dapat dilihat pada tabel berikit ini :

\begin{tabular}{|c|c|c|c|c|}
\hline No & $\begin{array}{c}\text { Jangka } \\
\text { Waktu } \\
\text { (Bulan) }\end{array}$ & $\begin{array}{c}\text { Jumlah Dana } \\
\text { Deposito } \\
(\mathrm{Rp})\end{array}$ & $\begin{array}{c}\text { Biaya Dana } \\
\text { Deposito } \\
(\%)\end{array}$ & $\begin{array}{c}\text { Tingkat } \\
\text { Bunga } \\
(\%)\end{array}$ \\
\hline 1 & 1 & $\begin{array}{c}8.245 .647 .000 \\
536.245 .120\end{array}$ & 0,2 \\
\hline 2 & 3 & $\begin{array}{c}10.112 .210 .00 \\
0\end{array}$ & 820.005 .450 & 0,3 \\
\hline 3 & 6 & $\begin{array}{c}12.792 .400 .00 \\
0\end{array}$ & 932.520 .721 & 0,4 \\
\hline 4 & 12 & \begin{tabular}{c}
7.106 .050 .000 \\
\multicolumn{2}{|c|}{ Jumlah }
\end{tabular} & $\begin{array}{c}38.256 .307 .00 \\
0\end{array}$ & $\begin{array}{c}2.584 .947 .80 \\
0\end{array}$ \\
\hline \multicolumn{2}{|c|}{ Rerata } & 9.564 .076 .750 & 646.236 .950 & 0,6 \\
\hline
\end{tabular}

Sumber : PT. BPR Tridarma Putri Klungkung

Dari tabel di atas dapat dicari biaya dana (Cost of Fund) rata-rata tertimbang deposito di PT. BPR Tridarma Putri Klungkung sebagai berikut : Cost of Fund deposito = 2.584.947.800/38.256.307.000 x 100\% = 6,75\%. Dengan melihat tabel 4.4 dan tabel 4.5 diatas hasil dari biaya dana (Cost of Fund) untuk tabungan sebesar 3,86\% dan biaya dana (Cost of Fund) untuk deposito sebesar $6,75 \%$, sehingga dapat dihitung besarnya total cost 
of fund (tabungan dan deposito) dari keseluruhan sumber dana di PT. BPR Tridarma Putri Klungkung.

Selanjutnya perhitungan cost of fund (tabungan dan deposito) secara keseluruhan di PT. BPR Tridarma Putri Klungkung dapat dilihat pada tabel dibawah ini :

Sumber : PT. BPR Tridarma Putri Klungkung

\begin{tabular}{|c|c|c|c|}
\hline $\begin{array}{c}\text { Sumber } \\
\text { Dana }\end{array}$ & $\begin{array}{c}\text { Jumlah Dana } \\
\text { (Rp.) }\end{array}$ & $\begin{array}{c}\text { Tingkat } \\
\text { Suku } \\
\text { Bunga } \\
(\%)\end{array}$ & $\begin{array}{c}\text { Biaya Dana } \\
(\mathrm{Rp})\end{array}$ \\
\hline $\begin{array}{c}\text { Deposito } \\
\text { Berjangka }\end{array}$ & 38.256 .307 .000 & 6,75 & 2.584 .947 .800 \\
\hline Tabungan & 44.002 .744 .792 & 3,86 & 1.698 .636 .036 \\
\hline Jumlah & 82.259 .051 .792 & & 4.283 .583 .836 \\
\hline
\end{tabular}

Dari tabel di atas dapat dicari total cost of fund untuk biaya dana deposito berjangka dan biaya dana tabungan sebagai berikut : Total Cost of Fund $=4.283 .583 .836 /$ $82.259 .051 .792 \times 100 \%=5,20 \%$

\section{Perhitungan Cost of Loanable Fund}

Besarnya tingkat bunga kredit yang dikenakan kepada nasabah. Harga pinjaman (loan pricing) sangat dipengaruhi oleh berbagai variabel yaitu cost of loanable fund, spread, biaya overhead, pajak, dan premi resiko yang diperkirakan semuanya dinyatakan dalam persentase tertentu.

a. Perhitungan cost of loanable fund

Untuk menghitung total cost of loanable fund, diasumsikan ketentuan Reserve Requirement (RR) untuk masing-masing sumber dana sebesar $5 \%$. Perhitungan cost of loanable fund dari keseluruhan sumber dana tersebut setelah memperhitungkan ketentuan RR dapat dilihat pada tabel dibawah ini :

\section{Rekapan Sumber Dana Tabungan dan Deposito Di PT. BPR Tridarma Putri Klungkung Tahun 2019}

\begin{tabular}{|l|c|c|c|c|c|}
\hline & Jumlah Dana & RR & $\begin{array}{c}\text { Penyaluran Kredit } \\
\text { Loanable Fund } \\
(\mathrm{Rp} .)\end{array}$ & $\begin{array}{c}\text { Tingkat } \\
\text { Bunga (\%) }\end{array}$ & $\begin{array}{c}\text { Biaya Dana } \\
(\mathrm{Rp} .)\end{array}$ \\
\hline $\begin{array}{l}\text { Deposito } \\
\text { Berjangka }\end{array}$ & 38.256 .307 .000 & 5,0 & 36.343 .491 .650 & 6,75 & 2.584 .947 .800 \\
\hline Tabungan & 44.002 .744 .792 & 5,0 & 41.802 .607 .552 & 3,86 & 1.698 .636 .036 \\
\hline Jumlah & 82.259 .051 .792 & & 78.146 .099 .202 & & 4.283 .583 .836 \\
\hline
\end{tabular}

Sumber : PT. BPR Tridarma Putri Klungkung

Dengan melihat tabel di atas dapat dicari perhitungan rata-rata tertimbang Total Cost of Loanable Fund dari keseluruhan sumber dana sebagai berikut :

Total Cost of Loanable Fund $=4.283 .583 .836 / 78.146 .099 .202 \times 100 \%=5,48 \%$.

Dari hasil perhitungan rata-rata tertimbang Total Cost of Loanable Fund tersebut diatas, maka Cost of Loanable Fund dapat dihitung pula $100: 95 \times 5,20 \%=5,478 \%$ (dibulatkan 5,48\%).

Jadi rata-rata tertimbang total cost of loanable fund harus selalu lebih tinggi dari cost of fund dimana Total Cost of Loanable Fund yang di dapat sebesar 5,48\% sedangkan total cost of fund sebesar 5,20\%. Reserve requirement sebesar $5 \%$ berarti dana yang dapat digunakan atau dipinjamkan sebenarnya adalah $100 \%-5 \%=95 \%$ 
b. Biaya Overhead

Biaya overhead yang dikeluarkan oleh bank adalah sebesar Rp. 7.215.898.984 sementara jumlah dana yang berhasil dikumpulkan Rp 82.259.051.792., maka biaya over head bank adalah : Biaya overhead 7.215.898.984:82.259.051.792 x $100 \%=8,77 \%$ Jadi biaya overhead untuk PT. BPR. Tridarma Putri Klungkung adalah $8,77 \%$.

c. Spread

Spread selalu dinyatakan dengan persentase, misalnya dalam menghitung tingkat suku bunga kredit (Base Lending Rate) bank menentukan spread sebesar 3,00\% dihitung dari perkiraan keuntungan yang diinginkan oleh bank.

d. Pajak sesuai dengan undang-undang di bebankan dari pendapatan kotor sebesar $1,00 \%$

e. Premi resiko

Dari pengalaman bank dalam pengelolaan kredit, yaitu dengan dilakukan penilaian atas kualitas kredit bermasalah. Semakin tinggi resiko yang di hadapi bank. Apabila diasumsikan outstanding loan atau saldo debet bank rata-rata sebesar Rp. 28.226.767.157 dan kolektibilitas kredit masing-masing, lancar 85\%, kurang lancar $6 \%$, diragukan 5\%, macet $4 \%$, maka jumlah kredit berdasarkan tingkat kolektibilitasnya dan jumlah cadangan penghapusan kredit dapat dihitung sebagaimana yang dilihat pada tabel adalah sebagai berikut :

\section{Jumlah Cadangan Penghapusan Kredit dari Outstanding Loan Sebesar Rp.28.226.767.157}

Di PT. BPR. Tridarma Putri Klungkung Tahun 2019

\begin{tabular}{|l|l|l|l|l|}
\hline Kolektibilitas kredit & $\begin{array}{l}\text { Kolektibilit } \\
\text { as kredit }\end{array}$ & $\begin{array}{l}\text { Kredit yang di } \\
\text { klasifikasikan } \\
\text { (Rp) }\end{array}$ & $\begin{array}{l}\text { Cad. } \\
\text { Penghap } \\
\text { usan }\end{array}$ & $\begin{array}{l}\text { Jumlah cadangan } \\
\text { penghapusan } \\
\text { (Rp) }\end{array}$ \\
\hline Cadangan umum & & & $1,0 \%$ & 200.000 .000 \\
Cadangan khusus & $85 \%$ & 26.026 .269 .475 & - & - \\
1. Lancar & $6 \%$ & 1.288830 .850 & $10 \%$ & 128.833 .085 \\
2. Kurang lancar & $5 \%$ & 556.764 .645 & $50 \%$ & 278.382 .232 \\
3. Diragukan & $4 \%$ & 354.902 .367 & $100 \%$ & 354.902 .367 \\
4. Macet & $100 \%$ & 28.226 .767 .157 & & 962.117 .684 \\
\hline
\end{tabular}

Sumber : PT. BPR Tridarma Putri Klungkung ( data diolah dari lampiran )

Dengan melihat tabel di atas maka premi resiko kredit rata-rata tertimbang PT. BPR Tridarma Putri Klungkung dapat dihitung sebagai berikut :

Premi Resiko $=962.117 .684: 28.226 .767 .157 \times 100 \%=3,40 \%$

f. Base Landing Rate

Selanjutnya dengan menggunakan angka-angka perhitungan tersebut diatas dapat ditentukan besarnya base landing rate PT. BPR Tridarma Putri Klungkung sebagai berikut :
1. Cost of Loanable Fund $=5,48 \%$
2. Overhead Cost of Money
$=8,77 \%$
3. Spread
$=3,00 \%$ 


$\begin{array}{lr}\text { COM+Spread } & =17,25 \% \\ \text { 4. Pajak 1\% } & =1,00 \% \\ \text { 5. Premi Resiko } & =3,40 \% \\ \text { Base Landing Rate } & =21,65 \% \\ & =======\end{array}$

\section{PEMBAHASAN}

1. Cost of Fund (Biaya dana) Tabungan yang seharusnya diberikan kepada nasabah di PT. BPR Tridarma Putri Klungkung dalam situasi pandemi Covid-19.

Tabungan adalah simpanan pihak ketiga pada bank yang penarikannya hanya dapat dilakukan menurut syarat-syarat tertentu yang telah disepakati seperti slip penarikan, buku tabungan, kartu ATM, atau sarana lainnya tetapi tidak dapat ditarik dengan cek, bilyet giro, atau alat lainnya yang dapat dipersamakan dengan itu sehingga yang mengakibatkan bank harus mengeluarkan Cost of fund (biaya dana) atas tabungan tersebut yang ada di PT. BPR Tridarma Putri Klungkung .

Cost of fund (biaya dana) adalah bunga yang dikeluarkan oleh bank untuk memperoleh dana simpanan baik dalam bentuk tabungan di PT. BPR Tridarma Putri Klungkung dalam situasi pandemi Covid-19 dapat dihitung berdasarkan jumlah tabungan, maka untuk mengetahui biaya dana bank harus dihitung berdasarkan rata-rata tertimbang untuk tabungan sebagai berikut : Cost of Fund tabungan =1.698.636.036 / 44.002.744.792 x 100\% = 3,86\%

Jadi berdasarkan hasil perhitungan Cost of fund (biaya dana) tabungan seharusnya sebesar $3,86 \%$, Sedangkan senyatanya Cost of fund (biaya dana) tabungan yang diberikan/berlaku sekarang adalah sebesa $4,00 \%$. berarti masih ada selisih sebesar $0,14 \%$.

2. Cost of Fund Deposito yang seharusnya diberikan kepada nasabah di PT. BPR Tridarma Putri Klungkung dalam situasi pandemi Covid-19.

Deposito atau simpanan berjangka adalah simpanan dana pihak ketiga pada bank yang penarikannya hanya dapat dilakukan dalam jangka waktu tertentu berdasarkan perjanjian antara pihak bank dengan nasabah yang bersangkutan penarikannya dapat menggunakan bilyet giro atau sertifikat deposito, sehingga yang mengakibatkan bank harus mengeluarkan Cost of fund (biaya dana) atas deposito tersebut yang ada di PT. BPR Tridarma Putri Klungkung.

Cost of fund (biaya dana) adalah bunga yang dikeluarkan oleh bank untuk memperoleh dana simpanan baik dalam bentuk deposito di PT. BPR Tridarma Putri Klungkung dalam situasi pandemi Covid-19 dapat dihitung berdasarkan jumlah deposito, maka untuk mengetahui biaya dana bank harus dihitung berdasarkan rata-rata tertimbang untuk deposito sebagai berikut : Cost of Fund deposito $=2.584 .947 .800 / 38.256 .307 .000 \times 100 \%=6,75 \%$

Jadi berdasarkan hasil perhitungan Cost of fund (biaya dana) deposito seharusnya sebesar $6,75 \%$, Sedangkan senyatanya Cost of fund (biaya dana) deposito yang diberikan/berlaku sekarang adalah sebesar $8,00 \%$. berarti masih ada selisih sebesar 1,25\%.

3. Base Lending Rate yang seharusnya diberikan kepada peminjam oleh PT. BPR Tridarma Putri Klungkung dalam situasi pandemi Covid-19.

Suku bunga adalah bunga yang dinyatakan sebagai persentasi dari modal. Suku bunga kredit/pinjaman adalah bunga yang diberikan kepada para peminjam atau harga dasar yang harus dibayar oleh nasabah peminjam kepada bank yang disebut dengan Suku Bunga Dasar Pinjaman (Base Lending Rate).

Base Lending Rate adalah formula untuk menghitung besarnya bunga / jasa pinjaman kepada para Debitur di PT. BPR Tridarma Putri Klungkung dalam situasi pandemi Covid-19 dapat dihitung berdasarkan jumlah tabungan, maka untuk mengetahui biaya dana bank harus dihitung berdasarkan cost of loanable funds, overheadcost, risk factor, spread dan tax di PT. BPR Tridarma Putri Klungkung adalah Base Landing Rate $=21,65 \%$ Jadi berdasarkan hasil perhitungan Base Lending Rate (Suku Bunga Dasar Pinjaman) 
seharusnya sebesar $21,65 \%$, Sedangkan senyatanya Cost of fund (Suku Bunga Dasar Pinjaman) yang diberikan/berlaku sekarang adalah sebesar $22,80 \%$. berarti masih ada selisih sebesar $1,15 \%$.

\section{KESIMPULAN}

Berdasarkan hasil pembahasan dalam penelitian ini, maka dapat disimpulkan adalah :

1. Cost of fund (biaya dana ) tabungan seharusnya sebesar $3,86 \%$, Sedangkan senyatanya Cost of fund (biaya dana) tabungan yang diberikan/berlaku sekarang adalah sebesa $4 \%$. berarti masih ada selisih sebesar 0,14\%.

2. Cost of fund (biaya dana) deposito seharusnya sebesar $6,75 \%$, Sedangkan senyatanya Cost of fund (biaya dana) deposito yang diberikan/berlaku sekarang adalah sebesar $8,00 \%$. berarti masih ada selisih sebesar $1,25 \%$.

3. Base Lending Rate (Suku Bunga Dasar Pinjaman) seharusnya sebesar $21,65 \%$, Sedangkan senyatanya Cost of fund (Suku Bunga Dasar Pinjaman) yang diberikan/berlaku sekarang adalah sebesar $22,80 \%$. berarti masih ada selisih sebesar $1,15 \%$.

\section{DAFTAR PUSTAKA}

Abdullah, Irwan, (1997). Sangkan Paran Gender. Yogyakarta, Pustaka Pelajar Offset.

Allan. 2005. Pengertian Internet dan asal usul dari kata internet, surabaya:penerbit indah.

Budisantoso, T dan Triandaru, S. 2006, Bank dan Lembaga Keuangan Lain,Salemba Empat: Jakarta.

B, Kasmir. 2008.Bank dan Lembaga Keuangan Lainnya.Edisi Revisi 2008.Jakarta:PT.Rajagrafindo Persada.

Dahlan Siamat, 2005. Manajemen Lembaga Keuangan. "Kebijakan Moneter dan Perbankan”, Jakarta : Fakultas Ekonomi

Universitas Indonesia, edisi kesatu.

Dendawijaya, Lukman. (2009). ManajemenPerbankan. Jakarta: Ghalia Indonesia.

Dwi Cahyo, F. (2020). Pengaruh Cost Of Loanable Fund, Overhead Cost, Risk Factor Dan Tax Terhadap Base Lending Rate Pada Perbankan Di Bei Periode Tahun 20152018 (Doctoral dissertation, Universitas Pancasakti Tegal).

Hasibuan, S.P Malayu (2005). Manajemen Sumber Daya Manusia. Edisi Revisi.Jakarta : Bumi Aksara.

Hasibuan, Malayu S.P, 2011. Manajemen Sumber Daya Manusia. Jakarta: PT Bumi Askara.

Hariani, F. D. (2015). Analisis Pengaruh Biaya Dana (Cost Of Fund) terhadap Pendapatan Bunga Pada PT BNI (Persero) Tbk (Doctoral dissertation, UIN Alauddin Makassar).

Ismail. 2010. Manajemen Perbankan Dari Teori Menuju Aplikasi.Jakarta: Kencana.

Kasmir. 2000.Manajemen Perbankan. Jakarta : PT.Rajagrafindopersada.

Kasmir. 2012. Dasar-Dasar Perbankan. PT Raja Grafindo Persada: Jakarta. 
Kasmir. 2014. Dasar-Dasar Perbankan.Edisi Revisi 2008. PT Raja Grafindo: Jakarta.

Kuncoro, Mudrajat, Suhardjono. 2011. Manajemen Perbankan Teori dan Aplikasi. Edisi ke 2. Yogyakarta: BPFE Yogyakarta.

Nurhuda, C. A. (2010). Analisis Pengaruh Cost Of Fund (Cof) Terhadap Base Lending Rate (BIr) Pada Pt Bank Rakyat Indonesia (Persero), Tbk PERIODE 2002-2008 (Doctoral dissertation, Universitas Muhammadiyah Surakarta).

Swasta Dharmesta dan Irawan,2010. Manajemen Pemasaran. Jakarta: PT. Gramedia Pustaka Utama Jakarta.

Sinungan, Muchdarsyah. 2000. Produktivitas Apa dan Bagaimana. Jakarta : Bumi Aksara.

Sukirno, Sadono. 2006. Makroekonomi: Teori Pengantar (edisi ke tiga). Jakarta: Rajawali Press.

Sugiyono. (2016). MetodePenelitian Kuantitatif, Kualitatif dan R\&D. Bandung: PT Alfabet.

Undang-Undang Republik Indonesia Nomor 7 Tahun 1992 Tentang Perbankan.

Undang-Undang Republik Indonesia nomor 10 Tahun

1998 tentang perubahan Atas Undang-Undang Nomor 7 Tahun 1992 tentang Perbankan dengan Rahmat Tuhan Yang Maha Esa.

Peraturan Pemerintah Republik Indonesia nomor 46 Tahun 2013 tentang pajak Penghasilan Atas Penghasilan dari Usaha Yang Diterima atau Diperoleh wajib Pajak yang Memiliki Peredaran Bruto Tertentu.

Prasta, A. A. G. A. A., \& Mahyuni, L. P. (2019). Racikan Strategi Pemberian Kredit di Bank Perkreditan Rakyat. Jurnal Manajemen Bisnis, 16(4), 32-57.

Pahlawan, H. (2016). Analisis Pengaruh Biaya Dana (cost of fund) Giro, Tabungan, dan Deposito terhadap Rentabilitas Bank Persero BUMN Indonesia 